\title{
First record of Acrothamnion preissii (Rhodophyta: Ceramiaceae) from the Maltese Islands (central Mediterranean Sea)
}

\author{
JULIAN EVANS, VERONICA FARRUGIA DRAKARD AND PATRICK J. SCHEMBRI \\ Department of Biology, University of Malta, Msida MSD2080, Malta
}

\begin{abstract}
The ceramiacean red alga Acrothamnion preissii is an Indo-Pacific species that was first recorded in the Mediterranean Sea (Italy) in 1969, and which subsequently spread within the north-western basin, reaching the Balearic Islands to the west and Sicily to the south. Here we record A. preissii from the Maltese Islands, which represents a further southwards expansion of its known distribution range in the Mediterranean Sea. Although this species can be invasive, becoming the dominant epiphyte by forming dense turfs that smother native species, so far there is no evidence for such an invasion phase in the Maltese Islands.
\end{abstract}

Keywords: Ceramiales, Malta, invasive species, alien species, range expansion

Submitted 22 June 2014; accepted 30 October 2014

\section{INTRロDUCTIDN}

Acrothamnion preissii (Sonder) E.M. Wollaston, 1968 is a filamentous red alga native to the Indo-Pacific region. In 1969, this species was discovered off the coast of Livorno, Italy (Cinelli \& Sartoni, 1969) and subsequently spread westwards, having been recorded from the Tuscan Archipelago (Papi et al., 1992; Pardi et al., 1993) and the Ligurian coast of Italy (Bianchi \& Morri, 1994), southern France (Boillot et al., 1982; Thélin, 1984), Monaco (Di Martino \& Giaccone, 1996) and the Balearic Islands (Ferrer et al., 1994). Acrothamnion preissii also extended its range in a southerly direction, with records from Naples (Guala et al., 2004), Ustica (Piazzi \& Cinelli, 2000) and Sicily (Giaccone \& Di Martino, 1996), and has more recently invaded the Adriatic Sea where it was found for the first time in Dubrovnik, Croatia (Despalatović et al., 2008).

In the Mediterranean Sea, A. preissii occurs mainly on living or dead rhizomes of Posidonia oceanica (Linnaeus) Delile, 1813 and amongst sciaphilic algae on vertical walls or overhangs, but it can also grow epiphytically on $P$. oceanica leaves or on macroalgae and on coralligenous or maerl bottoms down to a depth of $40 \mathrm{~m}$ (Ferrer et al., 1994; Piazzi \& Cinelli, 2003; Weitzmann et al., 2009; Klein \& Verlaque, 2011). This species can sometimes form dense turfs that trap sediment and smother underlying native species, thus reducing the species richness and functional algal diversity of the epiphytic macroalgal community where it occurs (Piazzi \& Cinelli, 2000, 2003; Piazzi et al., 2002). Acrothamnion preissii may have an economic impact since it can clog up fishing nets (Cinelli et al., 1984). It is therefore considered to be an invasive species (Boudouresque \&

Corresponding author:

P.J. Schembri

Email: patrick.j.schembri@um.edu.mt
Verlaque, 2002) and it has been included in the list of the 100 'Worst Invasives' in the Mediterranean Sea by Streftaris \& Zenetos (2006) and in the 'Black List of [Mediterranean] Marine Invasive Species' by Otero et al. (2013). At present, invasive populations of $A$. preissii are known from France, Italy, Monaco and Spain (Otero et al., 2013).

Here we present the first record of $A$. preissii from the Maltese Islands. This represents a southwards expansion of its known distribution range in the Mediterranean Sea by some $100 \mathrm{~km}$, which now extends to the central Sicilian Channel.

\section{RESULTS}

Tufts of algae containing filamentous rhodophytes were collected during a dive at Cirkewwa, on the northern coast of the island of Malta, in April 2014. Microscopic examination of this material revealed the presence of Acrothamnion preissii (Figure 1). In the field, this alga was preferentially growing as an epiphyte on the rhodophyte Phyllophora crispa (Hudson) P.S. Dixon, 1964 on a shaded vertical rock face beneath an overhang at depths of 20 to $25 \mathrm{~m}$. Although moderately common, A. preissii did not dominate the P. crispa epiphytic assemblage, which also included Chaetomorpha sp. Kützing, 1845, Feldmannia lebelii (Areschoug ex P.L. Crouan \& H.M. Crouan) G. Hamel, 1939, Halopteris filicina (Grateloup) Kützing, 1843, Heterosiphonia spp. Montagne, 1842 and another invasive red alga, Womersleyella setacea (Hollenberg) R.E. Norris, 1992. Acrothamnion preissii was also found growing on Cystoseira spinosa Sauvageau, 1912 on a horizontal rock platform at depths of 20 to $25 \mathrm{~m}$, but here it occurred at a much lower abundance than on P. crispa.

To assess whether $A$. preissii has a more widespread distribution in the Maltese Islands, surveys were made at two additional sites, one located a few kilometres away from 


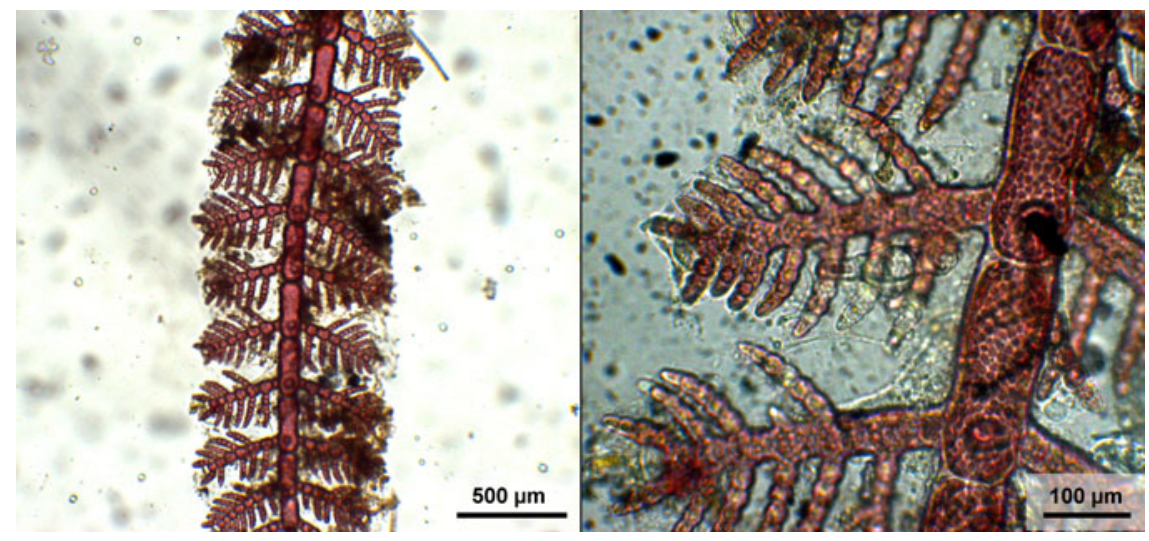

Fig. 1. Photomicrographs of Acrothamnion preissii collected from Cirkewwa, Malta (see Figure 2).

Cirkewwa, on the western side of the island of Malta, and the other on the west coast of the island of Gozo (Figure 2). No specimens of $A$. preissii were recorded from Gnejna, Malta. In the case of Dwejra, Gozo, a few tufts of this species were recovered from Cystoseira foeniculacea (Linnaeus) Greville, 1830 at a depth of $25 \mathrm{~m}$, indicating that $A$. preissii is present in the area but at a very low abundance. Filamentous rhodophytes did not form extensive turfs at any of the three sites surveyed.

\section{DISCUSSIDN}

Acrothamnion preissii is distributed in the north-western and central Mediterranean Sea. It is frequent along the Ligurian and adjacent southern French coasts and in the northern Tyrrhenian, and less common around the Balearic Islands, the central Tyrrhenian coast of Italy (Campania) and around Sicily (e.g. Klein \& Verlaque, 2011), but was not known to occur further south prior to the present record, despite detailed surveys for this species undertaken in other

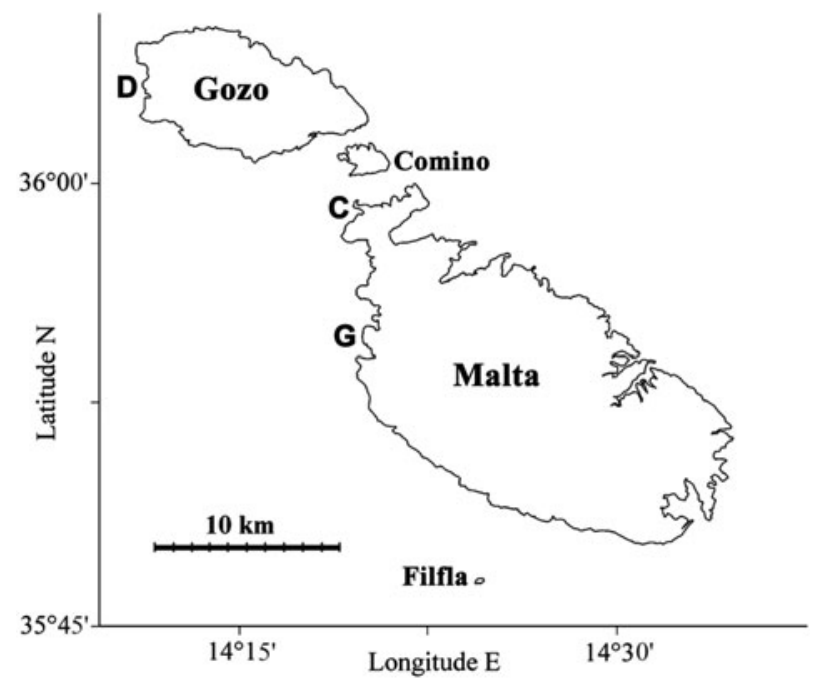

Fig. 2. Map of the Maltese Islands showing the location of the three sampling sites: Cirkewwa (C), Dwejra (D) and Gnejna (G). Acrothamnion preissii was present at Cirkewwa and with low abundance at Dwejra; it was not recorded from Gnejna. central Mediterranean sites (e.g. in Cape Bon [Tunisia], in Pantelleria and in Lampedusa; see Piazzi \& Cinelli, 2000; Piazzi et al., 2002; Furnari et al., 2010). Thus, the present report of $A$. preissii from the Maltese Islands represents the first record of this species from the central Sicilian Channel and indicates a southwards expansion of its distribution range by some $100 \mathrm{~km}$. Given that $A$. preissii is a small and inconspicuous alga that is not identifiable in the field, it can easily be overlooked and remain unnoticed in the absence of regular meticulous collection and examination of epiphytic assemblages (Piazzi \& Cinelli, 2000; Meinesz, 2007). Therefore, although there is an 18-year gap between the present Maltese record and that from Sicily in 1996 by Giaccone \& Di Martino (1996), this does not necessarily imply that $A$. preissii has extended its range recently. On the other hand, this species was not present around the islands in 1994-1995 when Cormaci et al. (1997) carried out detailed sampling of marine algae in Malta.

According to Sartoni \& Sarti (1976), the original introduction of $A$. preissii into the Mediterranean region was likely due to transportation via shipping activities. Its subsequent westwards expansion from Livorno along the northern coasts of the western Mediterranean basin may have occurred naturally due to the dominant currents in the area (Boillot et al., 1982), enabling $A$. preissii to spread via vegetative multiplication (Boudouresque \& Verlaque, 2002). On the other hand, its westernmost limit of distribution along the southern coasts of France is Marseille (Klein \& Verlaque, 2011), so the spread of $A$. preissii to the Balearic Islands may have involved human-mediated vectors of dispersal. No information on how this species spread southwards to Sicily and Malta exists, but this could include both natural range expansion and mechanisms based on anthropogenic activities; multiple introductions of species via different vectors are not uncommon (Verlaque et al., 2007).

The reported habitats of $A$. preissii from the Maltese Islands (as an epiphyte on macroalgae at depths of 20 to $25 \mathrm{~m}$, in low quantities on Cystoseira spp. and moderately common on the sciaphilic Phyllophora crispa) are similar to those elsewhere in the north-western Mediterranean Sea (e.g. Klein \& Verlaque, 2011). No examination of the epiphytes on Posidonia oceanica rhizomes was carried out, so it is not known if $A$. preissii also occurs in this habitat in the Maltese Islands. However, no extensive dense turfs were observed at any of the locations surveyed, including 
amongst $P$. oceanica beds. This indicates that thus far neither A. preissii nor Womersleyella setacea (from which A. preissii cannot be distinguished in the field) can be considered to be acting invasively in the infralittoral waters of the Maltese Islands, although $W$. setacea may be invasive on some maerl beds in the upper circalittoral (Sciberras et al., 2009). Whether these algae will persist without attaining a high biomass or eventually enter an invasion phase can only be ascertained by regular surveys of their reported habitats. Such monitoring is essential given that control of these species can only be carried out effectively early in the invasive process; once they become invasive, even containment may be impossible (Otero et al., 2013).

\section{ACKNOWLEDGEMENTS}

We are grateful to Enric Ballesteros (Centre d'Estudis Avançats de Blanes, CSIC) for confirming the identity of the species, to Vincenzo Di Martino (L'Istituto per i Sistemi Agricoli e Forestali del Mediterraneo, CNR) for supplying us with some hard-to-find literature and to Sandro Lanfranco (University of Malta) for the provision of laboratory facilities. Comments by Dr Cynthia D. Trowbridge (Oregon Institute of Marine Biology) and an anonymous referee helped improve the paper. This research was supported by the Albert II Foundation through the CIESM (Commission Internationale pour l'Exploration Scientifique de la Mer Méditerranée) project 'Tropical Signals'. Additional funding was received from the European Community's Seventh Framework Programme (FP7/2007-2013) under Grant Agreement No. 287844 for the project 'Towards COast to COast NETworks of marine protected areas (from the shore to the high and deep sea), coupled with sea-based wind energy potential' (COCONET).

\section{REFERENCES}

Bianchi C.N. and Morri C. (1994) Southern species in the Ligurian Sea (northern Mediterranean): new records and a review. Bollettino dei Musei e degli Istituti Biologici dell'Università di Genova 58-59 (1992-1993), 181-197.

Boillot A., Caram B. and Meinesz A. (1982) Sur l'Acrothamnion preissii Rhodophycée (Céramiale, Céramiacée) nouvelle pour la flore française. Cryptogamie Algologie 3, 21-24.

Boudouresque C.F. and Verlaque M. (2002) Biological pollution in the Mediterranean Sea: invasive versus introduced macrophytes. Marine Pollution Bulletin 44, 32-38.

Cinelli F. and Sartoni G. (1969) Acrothamnion J. Agardh (Rhodophyta, Ceramiaceae): genere algale nuovo per il mare Mediterraneo. Pubblicazioni della Stazione Zoologica di Napoli 37, 567-574.

Cinelli F., Salghetti Drioli U. and Serena F. (1984) Nota sull'areale di Acrothamnion preissii (Sonder) Wollaston nell'Alto Tirreno. Quaderni del Museo di Storia Naturale di Livorno 5, 57-60.

Cormaci M., Lanfranco E., Borg J.A., Buttigieg S., Furnari G., Micallef S.A., Mifsud C., Pizzuto F., Scammacca B. and Serio D. (1997) Contribution to the knowledge of benthic marine algae on rocky substrata of the Maltese Islands (Mediterranean Sea). Botanica Marina 40, 203-215.

Despalatović M., Grubelić I., Nikolić V., Dragičević B., Dulčić J., Žuljević A., Cvitković I. and Antolić B. (2008) Allochthonous warm water species in the benthic communities and ichthyofauna of the eastern part of the Adriatic Sea. CIESM Workshop Monographs $35,51-57$.

Di Martino V. and Giaccone G. (1996) Biodiversità in associazioni dipendenti di epibionti vegetali in prati a Caulerpe nel Mediterraneo. Biologia Marina Mediterranea 3, 32-39.

Ferrer E., Ribera M.A. and Gómez Garreta A. (1994). The spread of Acrothamnion preissii (Sonder) Wollaston (Rhodophyta, Ceramiaceae) in the Mediterranean Sea: new record from the Balearic Islands. Flora Mediterranea 4, 163-166.

Furnari G., Giaccone G., Cormaci M., Alongi G., Catra M., Nisi A. and Serio D. (2010) Macrophytobenthos. Biologia Marina Mediterranea 17 (suppl. 1), 801-828.

Giaccone G. and Di Martino V. (1996 [published 1998]) Flora, vegetazione marina e stato dell'ambiente nell'area iblea. Bollettino dell'Accademia Gioenia di Scienze Naturali di Catania 29, 359-391.

Guala I., Esposito A. and Buia M.C. (2004) Biodiversity of macroalgal assemblages in the Gulf of Naples. Poster presented at the Incontro scientifico congiunto CoNISMa - AIOL d'intesa con la S.I.B.M. e la S.It.E. 'Le scienze naturali, economiche e giuridiche nello studio e per la gestione degli ambienti acquatici', Palermo, Sicily, 18-22 October 2004. Available at: http://www.conisma.it/incontro-conisma-aiol/ poster.html

Klein J.C. and Verlaque M. (2011) Macroalgae newly recorded, rare or introduced to the French Mediterranean coast. Cryptogamie Algologie 31, 111-130.

Meinesz A. (2007) Methods for identifying and tracking seaweed invasions. Botanica Marina 50, 373-384.

Otero M., Cebrian E., Francour P., Galil B. and Savini D. (2013) Monitoring marine invasive species in Mediterranean Marine Protected Areas (MPAs): a strategy and practical guide for managers. Malaga, Spain: IUCN, $136 \mathrm{pp}$.

Papi I., Pardi G., Lenzini S., Benedetti Cecchi L. and Cinelli F. (1992) Benthic marine flora in the Tuscany Archipelago. A first contribution: isles of Capraia, Elba, Formiche di Grosseto, Giglio, Scoglio d'Africa, Montecristo and Giannutri. Giornale Botanico Italiano 126, 549-593.

Pardi G., Papi I., Piazzi L. and Cinelli F. (1993) Benthic marine flora in the Tuscan Archipelago. A second contribution: isle of Gorgona. Giornale Botanico Italiano 127, 797-819.

Piazzi L. and Cinelli F. (2000) Effets de l'expansion des Rhodophyceae introduites Acrothamnion preissii et Womersleyella setacea sur les communautés algales des rhizomes de Posidonia oceanica de Méditerranée occidentale. Cryptogamie Algologie 21, 291-30o.

Piazzi L. and Cinelli F. (2003) Evaluation of benthic macrolagal invasion in a harbour area of the western Mediterranean Sea. European Journal of Phycology 38, 223-231.

Piazzi L., Balata D. and Cinelli F. (2002) Epiphytic macroalgal assemblages of Posidonia oceanica rhizomes in the western Mediterraean. European Journal of Phycology 37, 69-76.

Sartoni G. and Sarti M. (1976) Sulla presenza a Livorno di Aglaothamnion feldmanniae L'Hardy-Halos. Informatore Botanico Italiano $8,185-187$.

Sciberras M., Rizzo M., Mifsud J.R., Camilleri K., Borg J.A., Lanfranco E. and Schembri P.J. (2009) Habitat structure and biological characteristics of a maerl bed off the northeastern coast of the Maltese Islands (central Mediterranean). Marine Biodiversity 39, 251-264.

Streftaris N. and Zenetos A. (2006) Alien marine species in the Mediterranean - the 100 'Worst Invasives' and their impact. Mediterranean Marine Science 7, 87-118. 
Thélin I. (1984) Nouvelle signalisation d'Acrothamnion preissii (Sonder) Wollaston sur les côtes françaises de Méditerranée. Travaux scientifiques du Parc nationale de Port-Cros 10, 171-172.

Verlaque M., Ruitton S., Mineur F. and Boudouresque C.F. (2007) CIESM atlas of exotic macrophytes in the Mediterranean Sea. Rapport du Congrès de la Commission Internationale pour l'Exploration Scientifique de la Mer Méditerranée 38, 14.

and
Weitzmann B., García M., Cebrián E. and Ballesteros E. (2009) Les invasions biologiques en el medi marí: exemples i impactes a la Mediterrània Occidental. L'Atzavara 18, 39-49.

\section{Correspondence should be addressed to:}

P.J. Schembri

Department of Biology

University of Malta

Msida MSD2080, Malta

email: patrick.j.schembri@um.edu.mt 